\title{
Globalizing Drag in the Cook Islands: \\ Friction, Repulsion, and Abjection
}

Kalissa Alexeyeff

$\mathrm{T}_{\mathrm{h}}$ his article is about a Drag Queen competition I attended on Rarotonga, Cook Islands, in I998. ${ }^{1} \mathrm{I}$ am returning to it because it continues to perplex me-much as it did the audience on the night it was held. It was a show that combined elements of "Western" drag shows and beauty pageants, and "local" styles of cross-dressing and performing. This combination in itself is not unusual; drag queen competitions that meld local and nonlocal styles of drag performance have been held on Rarotonga since at least the I980s. This particular show included performances that resulted in the show being judged by many in the audience as less than entertaining and, at times, highly distasteful. These sentiments were summed up in the aftermath, as the unanimous reaction to the competition was, "It was stink."

This show was received in a strikingly different way from the many other drag and cross-dressing performances I attended in the Cook Islands, which are generally viewed as extremely humorous and enjoyed by diverse audiences. These performances traverse many contexts: fundraising events for church groups, sports competitions, Independence Day celebrations, and Christmas dance competitions. Usually they involve male groups in female costumes dancing to intricately choreographed performances of local female dances. Solo cross-dressing performances are most common at drag shows or in spontaneous "clowning" among friends at nightclubs or parties.

I suggest that the failure of the 1998 Drag Queen competition derived in part from some of the participants' idiosyncratic interpretations of drag and a broader epistemological "category crisis" in attempts to amalgamate Western and local forms of drag. My understanding is partly inspired by Marjorie Garber's observations of how transvestite figures in Western

The Contemporary Pacific, Volume 20, Number I, I43-I6I

(C) 2008 by University of Hawai' $i$ Press 
culture are used to signify a "'category crisis,' disrupting and calling attention to cultural, social, or aesthetic dissonances" (I992, I6). I consider a different cultural context than Garber, but the main tenor of her argument resonates in the Cook Islands context and the 1998 Drag Queen competition.

The category crisis of the 1998 Drag Queen competition reveals important tensions between Western and local understandings of sexual and gendered identities, which have implications for how we theorize crosscultural encounters and, more broadly, the dynamic intersections between local and non-local forces and practices. In contrasting local and Western—or papa'a (white, in Cook Islands Māori)—I am not suggesting that the local and global/West are simply opposed. Rather, Cook Islands "locality" is molded by the interplay between competing perspectives; Western and local are co-present in a zone of contestation, and Cook Islanders struggle over their meaning and aim at legitimating their understandings of the terms "local" and "Western."

In the first section of this article, I explain my approach to the I998 Drag Queen competition by considering globalization and cultural exchange through debates about the interaction between local and Western notions of gender and sexuality. The majority of men who perform in these kinds of competitions are known as laelae; in the second section I provide an overview of how this category of person intersects with Cook Islands' notions of masculinity, femininity, and "third gender" (Herdt I994). I then examine the 1998 Drag Queen competition, analyzing how performers combined local and Western elements, and how audience members received them. To understand the audience responses, I use Julia Kristeva's understanding of abjection as a process of expulsion and repulsion that serves to reinscribe category definitions (Kristeva I982; see also Butler I990). I suggest that abject configurations of motherhood and domesticity are used to signify inherent tensions between local and Western notions of gender and sexuality.

What are the political and cultural stakes in writing about such an intensely personal topic as sexuality? My discomfort at delving into private arenas in cross-cultural contexts has resulted in my focus on public performances of, and discourses on, gender and sexuality. In this article my primary interest is in the tensions between localization and globalization, and performances that trouble normative cultural identities, both indigenous and exogenous. Sexuality, as a number of scholars remind us, is "a dense transfer point of power" (Stoler and Cooper I997, 26; McClintock I995; 
Garber I992; Foucault 1978). In the performance examined here, sexuality becomes a potent vector for ideas about the relationship between local and global, and the anxieties and dissonances that encounters between the two can create. ${ }^{2}$

\section{Globalization and Cultural Exchange}

A number of scholars of globalization and sexuality predict the increasing homogenization of cultural forms on a global scale. So, Dennis Altman, in his work on "global gay" (I996, 200I), has argued that there is a clear connection between the expansion of consumer society and the global growth of overt gay identity. Globalization has opened up possibilities for a rapid spread of homosexuality as a social, political, and commercial identity. In this configuration, "global gay" constitutes a proliferation and expansion of Western models of homosexuality.

In contrast to Altman's approach to globalization through political economy, the work of many anthropologists has aimed to study "globalization from below" (Appadurai 200I, 3; Tsing 2002; Iwabuchi 2002; Howes I 996). The latter perspective suggests that cross-cultural encounters involve reciprocal exchange rather than an inevitable process of cultural homogenization. In debate with Altman, Peter Jackson has argued: "The mere existence of the word "gay" in the contemporary Thai language does not indicate that a global gay identity or a transnational homogenization of human sexuality is a necessary outcome of the impact of yet another universalizing world culture. ... Western notions of homosexuality and gay identity are also being accommodated within the Thai cultural framework, in the process becoming as much Thai as Western, if not more so" (Jackson I996). In previous work I have similarly highlighted local agency in processes of cultural exchange (Alexeyeff 2000, 2004), concretely mapping how global forces are actively incorporated into local repertories, and at the same time, how local systems of value are annexed or oriented to the global.

Exemplifying two-way exchanges, Drag Queen competitions in the Cook Islands clearly draw from Western drag shows, but they do not simply mimic Western genres. Rather, the appropriation is preeminently incorporation and reconstitution of "the West" in local forms. Such Drag Queen competitions are oriented inward, replete with local aspirations, but are simultaneously oriented outward: they reference, and are situated in, a broader "global" context. Many contestants purposefully orient their 
displays of local "drag" practices to cosmopolitanism, adopting obviously Western postures, music, dress, and so on (Besnier 2002). So while Drag Queen competitions evince local appropriation, they also reveal the globalization of locality. Thus any opposition between global homogeneity and local appropriation is a facile and false dichotomy. Rather, engagement with global flows creates complex entanglements that are neither local nor global, but exist in dynamic combination.

Here Anna Tsing's metaphor of "friction" (2002, 2005), describing the increased density of cross-cultural encounters in the era of globalization, is useful. Friction enables the "grip of encounter" like the hold between different moving surfaces (Tsing $2005, \mathrm{I}$ ). Tsing has argued that this metaphor enables us to stop making a distinction between "global" forces and local places, as all place-making and all force-making are both local and global (2002, 477).

But can Tsing's inspiring model of friction in globalized cross-cultural encounters help to explain why the 1998 Drag Queen competition was "stink"? The encounter produced in this competition was not the interactive connection or "creative friction" that produces a compelling grip (Tsing $2005, \mathrm{x}-\mathrm{xi}$ ); it more closely resembled the forceful repulsion created when the same ends of two magnets are forced together. ${ }^{3}$

This question challenged some of my assumptions about the positive intersection of local and Western. Concentrating on how the West is actively appropriated into local forces enables one to focus on local agency in the emergent shape of cross-cultural encounters, and privileges those that are productive, positive, or generative. Like many others, I have tended to emphasize creative encounters, those in which Cook Islanders incorporate and appropriate outside cultural flows into local currencies of value, a process that effects the "domestication of the West" (Cannell I 995 , 25I). Put another way, I have been concerned to show how Cook Islanders access and transform foreign power in order to reconstitute it for local uses (Stoller I995, I95).

Performances like the 1998 Drag Queen competition disrupt such analyses of harmonious cultural encounter. Unlike most cross-dressing performances in the Cooks (which have proved hugely popular no matter how amateur the performance), this drag competition was a manifest failure. It suggests that attention to local agency is crucial since such emphasis on reciprocal exchange often implies notions of hybridity that elide the potential violence and repulsion accompanying exchange. As Fran Martin 
has argued (2003, 36, drawing from the work of Jacqueline Lo [2000]), notions of "happy hybridity" are uncritically celebratory, and neglect exchanges that produce ambivalent, unproductive, and even disastrous effects.

\section{CROSS-DRESSING IN THE COOKS}

Cook Islands cross-dressing performances articulate versions of Cook Islands masculinity, femininity, and local "third gender" identity. As many scholars of sexuality in non-Western countries have observed, "straight" and "gay" mean quite different things than in the West. In the Cook Islands homosexual men are called laelae, a category of feminized masculinity that is common throughout the Pacific (Wallace 2003; Elliston 1999; Mageo I996; Besnier 1994; Shore I98 I; Levy I973). The term "laelae" is used to describe a wide range of peoples and practices. Some laelae view themselves as women trapped in men's bodies; others see themselves as both women and men, possessing the finer attributes of both sexes. Yet others view laelae as a distinct category of person-neither man nor woman. Some laelae dress in women's clothing, normally local-style sarongs and T-shirts, others may wear men's clothes but keep their hair long, tied in a bun in the manner of women, and perhaps wear women's jewelry, nail polish, or lipstick. Laelae who adopt female accoutrements also tend to adopt feminine comportment, such as a graceful walk and soft voice. A minority of laelae in the Cook Islands dress and act like "straight" men.

Laelae is also used to describe men who are presumed to be heterosexual but are considered effeminate in some regard. Men of slight stature, those who engage in white-collar, intellectual work not manual labor, who are friendly with women, or are single past their mid-thirties, are often referred to as laelae. Finally, actions that are considered unmanly may lead to someone's being categorized as a laelae; frequently young boys are told they are acting like a laelae if they cry, show fear, or express similar "feminine" emotions.

A key difference between laelae and Western homosexuals is that selfidentified laelae sexually desire straight men, not other laelae. Laelae I spoke to found the idea of having sexual relations with another laelae as largely incomprehensible and likened it to sleeping with someone of the same sex. Straight men who have sex with laelae are not considered, and do not consider themselves, to be homosexual. However, these men are 
not open about sleeping with laelae; indeed, both laelae and their straight partners face physical violence from family members if discovered to be engaging in sexual liaisons (see Alexeyeff forthcoming).

Western notions of homosexuality are familiar to Cook Islanders who belong to transnational networks that incorporate family and friends primarily in Aotearoa/New Zealand, Australia, Tahiti, and North America. These networks mean that most Cook Islanders are aware of sexual norms elsewhere. Tourism is the main industry in the home islands, and gay tourists, Western television and film, and religious discourse all circulate ideas, albeit contesting, about Western homosexuality.

Knowledge of Western homosexuality has not resulted in the adoption of global gay identities in any straightforward manner. Some laelae adopt aspects of Western homosexuality into their self-presentation; these are usually men who have spent some time abroad, and are seen as having been influenced by papa'a ways in the clothes they wear, their competency in English, and their educational skills-but not in terms of sexual preference (which, for laelae I knew, continued to be for straight men).

Some laelae playfully borrow Western homosexual terms and practices, especially in performative situations like the 1998 Drag Queen competition described here, and during private parties with friends. One Rarotongan laelae, for example, was fond of describing himself as, "the paramount queen of the island." This humorous identification played on the double meaning of the Western term "queen" to describe flamboyant gay men, and the Cook Islands' usage "queen," the name frequently given to female ariki, traditional chiefly women.

Commonly, laelae identity is actively defined in opposition to Western homosexual identity. Often non-laelae Cook Islanders express distaste at laelae sexual proclivities or deny that laelae are sexual beings. "Gays sleep with men, not laelae," is a frequently heard assertion. This is not simply a case of homophobic disavowal. While there is ambivalence about laelae sexuality, laelae are simultaneously accepted members of family groups, and are widely admired for their talents, particularly as dancers, singers, and composers, and their accomplishments at female tasks such as sewing. Rather, this understanding of laelae identity suggests a different configuration of personhood, where gender is considered more important to identity constitution than sexuality. ${ }^{4}$

Gender rather than sexual identity is given ontological priority in the Cook Islands and the Pacific more widely (Alexeyeff forthcoming; see also Besnier 1994). Laelae are primarily defined in relation to the gendered 
division of labor. Laelae tend to engage in women's work such as cooking, cleaning, sewing; they socialize predominantly with women, and undertake caring roles such as looking after children and elderly relatives. While sexual orientation is regarded as central to Western understandings of homosexuality, this aspect of laelae identity is deemphasized by non-laelae and by laelae themselves. This configuration of sexuality points to very different understandings of the constitution of the self. In Western contexts sexuality is often viewed as originary, or primary and productive of existence, as the core of individual psychology and hence the make-up of the self (Foucault I978). In many non-Western contexts, the self is defined less in individualist, atomistic terms, and more relationally (Wallace 2003; Besnier 1994). Collective life, social context, and kinship relations take priority over individual desires and personal motivations.

Thus, the intersection of Western and local ideas of homosexuality in the Cook Islands produces a series of complex effects. In some contexts Western ideas and practices are accommodated, adopted, and happily hybridized. But in other situations the encounter produces awkward and uncomfortable results, as it did in the 1998 Drag Queen competition.

\section{DANCING QUEENS}

The 1998 Drag Queen competition was held at TJ's nightclub in Avarua on a Wednesday night. The venue was full an hour before the show was to begin. The audience included friends and family of the contestants and young men and women who regularly went out to nightclubs. An L-shaped catwalk draped with leafy foliage had been constructed to extend from the dance floor. Chalked onto a large blackboard behind the catwalk was "Drag Queen 1998," and the names of the sponsors: Air New Zealand, the major airline carrier to the Cook Islands and sponsor of many cultural events, and the Printing Company, a local manufacturing business. The emcee (master of ceremonies) was a female netball champion. At the beginning of the competition she introduced three male judges sitting on separate tables on the edge of the dance floor: a representative from Air New Zealand, the local news reader, and the special events co-coordinator of Tourism Cook Islands. After a brief prayer conducted by the emcee, the competition began with the emcee's invitation: "Let's welcome the ladies with the extras."

The event was modeled on Western-style drag shows and beauty pageants. Five contestants participated in three sections: pareu (beachwear), 
talent, and eveningwear. In the beachwear section, some of the contestants paraded to iconic drag songs such as "You Sexy Thing" (Hot Chocolate) and "I'm a Barbie Girl" (Aqua). Many of the performances also involved demonstrating skill at dancing in local female style while humorously playing with conventions of femininity. Many performances creolized aspects of Western and local music and dance: some performers chose local stringband songs to accompany local dances, or performed Cook Islands 'ura (dance) moves to Western songs. Such creolization in expressive culture is common in the Cook Islands (see Alexeyeff 2004).

During the beachwear section, the emcee introduced each of the five contestants by their stage names, all highly cosmopolitan and glamorous: Claudia, Lahaia, Shania, Lady Posh, and Cher. She also read out a brief description of each contestant. Claudia, for example, was introduced as "representing the beautiful village of Tupapa Maraerenga. She wants you to know she is both old enough and young enough. And she is still a virgin. Her hobby is dreaming. And her ambition is to be the best housekeeper on the island. Her rates are cheap; only three dollars an hour." In the talent section of the competition, the contestants also played with combinations of Western drag shows and local cross-dressing performances. Claudia, in keeping with her housekeeping ambitions, performed to the ABBA song "Dancing Queen" in tiny cut-off denim shorts, a shirt tied to reveal her slender belly, and a scarf tied around her head. Her props were a bucket full of soapy water and a large sponge. She scrubbed, gyrated, and rolled around the floor.

Other contestants similarly foregrounded their domestic rather than sexual prowess. Lahaia's articulated ambition was to be "a good caretaker"; her whole performance was based around her advanced pregnancy. Similarly, the emcee told the audience that Cher (who had a prominent beer gut) was six months pregnant and had joined the competition to find a nice single boy who would take care of mother and child.

Throughout the competition, various aspects of Cook Islands' femininity were displayed. The majority of contestants combined Cook Islands' dancing with Western dance movements. Cook Islands' female comportment was adopted on the catwalk; this involved graceful movements that were sensual without being overtly sexual. Shania, in particular, appeared throughout the competition as the embodiment of shy, self-effacing Rarotongan femininity, a figure sanctioned by hegemonic Cook Islands' norms. Her eyes were downcast throughout the beachwear section, her sarong was tied in a modest style, and she did not open it to reveal her bikini 
as the other contestants did. Shania was the only contestant in the talent section to perform a strictly Cook Islands' female dance number, dancing to an old Cook Islands' song in a "straight" female costume-coconut bra, sarong, and titi (leafy overskirt). To an extent, her shyness impeded her performance. The audience was largely silent except for a few bursts of supportive applause when she attempted some slightly raunchy moves. The audience was more appreciative, however, when her titi fell off, as that provided comic relief to an otherwise dull performance.

In most performances, ideals of local femininity were combined with "Western" elements of music, dance moves, and clothing. However, local aspects of Cook Islands' femininity were privileged through two main signifiers: domesticity and motherhood. These are central to Cook Islanders' ideals of femininity and feminine virtue. Domestic cleanliness is a key value despite contemporary women's extensive involvement in paid work, politics, and community affairs. Women who conform to this ideal sweep their houses daily, dust regularly, keep their family's clothes spotlessly clean and ironed, and rake their gardens for leaves every second day. ${ }^{5}$ Women who do not embrace regimes of domestic cleanliness are often spoken about disparagingly as "bush ladies," their houses described as pigsties, and their character implied to be less than virtuous. Being dirty, in other words, is considered actively antisocial, bestial, and demonstrating an inability to care for family. Laelae tend to prefer women's work, their domestic cleanliness is celebrated, and they are thought to be talented cooks, sewers, and weavers. In the domestic sphere, laelae are often seen as "more womanly than women" (Besnier I994, 297).

Motherhood is thought of as defining female maturity and as the pinnacle of Cook Islands' femininity. Girls tend to have children in their early twenties; many do not publicly declare the identity of the father of their children, nor do they marry until their thirties. All religious leaders decry the practice of bearing children out of wedlock, and intense gossip and speculation accompany these pregnancies, but the practice goes on unabated, due in part to the value placed on children and family, by kin and by society at large. Laelae and women who cannot have children may "adopt" children from family members so they are not "lonely" (a longstanding local practice called angai tamariki, feeding children). In informal interactions, laelae often jokingly play with ideas of being pregnant. At a party where I was present, one laelae complained of having an upset stomach, to which another quickly replied, "It must be morning sickness," to the amusement of those in earshot. On another occasion a 
laelae dramatically grabbed his stomach: "All that beer I drank, look at my stomach, I think I am pregnant!” Thus, contestants' framing of their performances through domesticity and motherhood—and their humorous subversion-alludes to the preeminent values of such practices in everyday life, and in collective ideals.

In contrast to the other four contestants, Lady Posh's performance most closely resembled a Western drag performance (photo I). The performer had spent most of his life in New Zealand, studied fashion design, and returned to "the islands" to experience life in his homeland and to teach art at the high school for a while. He identified as gay and laelae, cleverly shaping his self-presentation depending on the contexts in which he found himself. For example, in situations that were particularly local, such as church and family events, he toned down the more flamboyant aspects of his behavior, particularly those that involved the display of sexuality, while overtly displaying this sexual directness at parties and nightclubs. In the drag show he presented himself in highly sexual terms, and as possessing the best physical attributes of both sexes. The emcee also introduced him as Lady Posh in overtly sexual terms: "Her measurements are 38, 2I inches [Lady Posh massaged her "breasts" and slid her hands down to

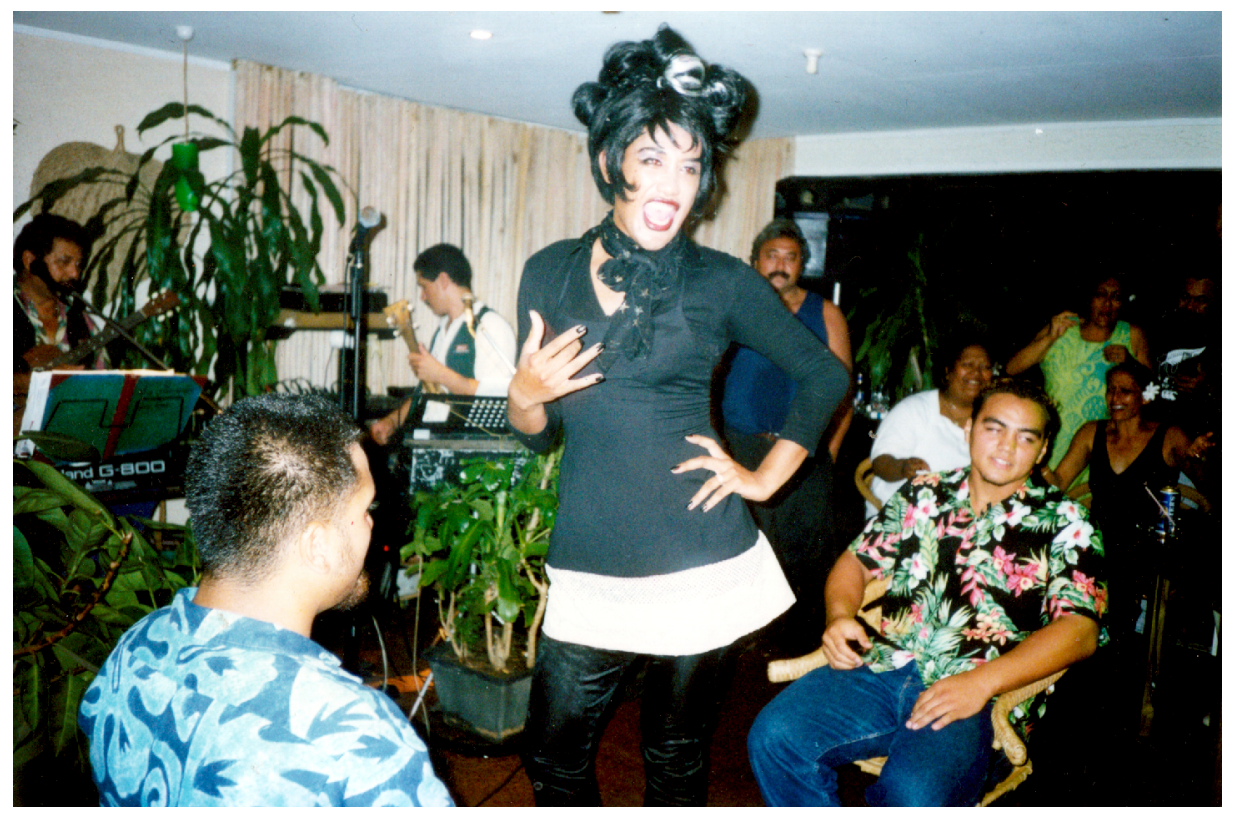

Рното I. Lady Posh and her volunteers. Photo by author. 
her waist], "and I9" [she grabbed her penis], "but 30 at her full potential" [she slid her hands up and down her inner legs]." Lady Posh's talent section performance was a lip-synched dance to the Tina Turner classic, "River Deep, Mountain High"-which resembled a Western drag-style performance, disco dancing, and striptease, combined with Cook Islands 'ura movements. The audience-as sophisticated purveyors of Western drag-appreciated this polished performance. Lady Posh went on to win the competition.

The reception of Lady Posh's performance was marred only by the actions of one audience member. As part of the performance, Lady Posh enlisted the participation of two male audience members, getting them to sit on chairs facing each other as she performed between them. One of the men was what is termed a "local local"; he had spent all his life on Rarotonga, and worked as a manual laborer at the Cook Islands Transport Company. He was also somewhat of a clown; he acted humorously when he performed in his village's sports and dramatic events. The other man was a Cook Islander born and raised in Melbourne, Australia. This was his first visit home, with the Melbourne Cook Islands rugby team who were touring. Several of the team attended the performance and, in contrast to the majority of the local audience, they jeered the performers, shouting out sexualized comments and wolf-whistling. At one stage the emcee had to ask them to be quiet. Their behavior was noted by others in the audience, who also chided them with the phrase "Maniania kotou!" (You are making too much noise!)

As the performance progressed, the two men began to interact with Lady Posh. Both encouraged her to face them and dance toward them. The "local local" responded as if he was dazzled by Posh's performance and jokingly threw himself around on his chair as Lady Posh danced seductively in his direction. The Melbourne man, in contrast, responded in a highly sexual manner, trying to grab Lady Posh's breasts and bottom. As the performance was reaching the end, the "local local" stood as Lady Posh started to dance the female "ura, he joined in by exaggeratedly dancing in the same style- a move the audience loved, and responded to with cries of appreciation. The Melbourne Cook Islands man also stood and began to act out male copulating moves with Lady Posh, which silenced audience laughter, produced some "tsk-tsk-ing" and the revealing comment, "Tourist e koe?" (Are you a tourist?). The "local local" jokingly gestured for him to stop, miming, "She is mine." As this did not serve to 
deter the Melbourne man, the "local local" grabbed both him and Lady Posh in an all-encompassing embrace.

The divergent reactions of the two young men were revealing in terms of my earlier argument about unproductive encounters between local and global forces. The "local local" man responded in a way that conformed to local practices about performative humor involving mimicry of female comportment and contributed to the hilarity of Lady Posh's number. In contrast, the Melbourne-based Cook Islander's overtly masculine sexual movements served to make Lady Posh uncomfortable, and the audience's reaction suggested that it detracted from the entertainment. It was identified overtly by at least one audience member as a touristic reaction, one that foregrounded sex and licentiousness in relationships between locals and outsiders (Jolly 1997). The Melbourne Cook Islander however was not a papa'a, and as a Cook Islander he should have known the appropriate style of participation. As such, this performance began to signal a tension between Cook Islanders' perceptions of local and Western sexuality and gender and their presentation in performative contexts. This tension became increasingly potent as the competition progressed, revealing an active repulsion between Western and local categories of sex and gender.

\section{BREASTS AND BABIES}

Two other contestants presented highly idiosyncratic performances that received extremely lukewarm responses from the audience. In her talent section, Cher circled the audience in a black cape, her face covered with an oriental-style mask. Cher then threw off the cape to reveal her outfit, a pair of large fake white breasts, and black leggings with a lacy white G-string over the top. As heavy metal music started, she produced a skateboard with a tropical scene painted on it, attempted to skate, and finished her number playing air-guitar. The performance was considered very unusual for two reasons. First, heavy metal music is not popular in the Cook Islands; reggae and soul dominate the contemporary music scene. This choice of music meant that the audience did not react enthusiastically to this performance, which was considered quite bizarre. Second, the audience collectively gasped as Cher revealed her large fake breasts, which were massaged throughout the performance. These breasts and their treatment were discussed later as "stink" and also "dirty," as beyond the bounds of decency, and a scandalous failure in terms of audience expectations. 
Lahaia's performance also featured fake breasts, which again produced uneasiness among the audience. Lahaia's theme for the evening was pregnancy. In the beachwear section she wore a black one-piece bathing suit that revealed her pregnant stomach. She lay down on the dance floor as though sunbathing and oiled herself with coconut oil. Her talent section was an enactment of the birth of her child. In a black sarong and a black bra with enlarged nipples attached, Lahaia wheeled in a pram with a sign on it: "International Year of the Child. Alcohol??? Healthy Mum gets Healthy Baby. Stop the Violence." Like some of the earlier performances, Lahaia's referred to certain ideas of Cook Islands motherhood and domesticity. It was also placed in an international context apropos the rights of the child, rights pertaining to bodily security and referencing local issues of high rates of alcohol consumption and maternal health. Lahaia then lay on the floor and "gave birth" to a puppy, cut off the "placental cord" with a saw, and began to breast-feed the pup. It was this aspect of the performance that created the most disquiet in the audience. As the puppy was born, people in the audience gasped and some laughed nervously. Over the next few days, people commented on how they had never seen anything like her performance. The main assessments were how strange it was, and again, how "stink."

What intrigued me about both Lahaia's and Cher's performances was their spectacular failure, both in terms of Western drag-show and local cross-dressing and performance genres. It was not that the audience or performers did not grasp the displays of non-local drag forms. Indeed, the most popular performer (and winner of the competition) was the one who most closely approximated a Western drag performance. The contestants who most attempted to meld Western and local forms produced a decidedly unenthusiastic response from the audience.

What I believe occurred during the competition was that the encounter between the local category of laelae and the Western category of gay seemingly did not lend themselves to successful mixing. In order to unpack the tension in this encounter, I start with the most obvious source of audience displeasure-the breasts. In her seminal work "Breasted Experience" (I990), Iris Marion Young argued, "Breasts are a scandal because they shatter the border between motherhood and sexuality. Nipples are taboo because they are quite literally, physically, functionally undecidable in the split between motherhood and sexuality" (Young 1990, 199; italics and spelling in original). 
While Cook Islands patriarchy operates in culturally specific ways that must take into account the role of missionary, colonial, and postcolonial forces in molding local male domination, Young's comments are still surely applicable. In the I998 Drag Queen show, Cher's and Lahaia's breasts transgressed the boundaries of motherhood and sexuality-both had stated that they were pregnant in their introductory comments. The audience's reactions to Cher's fondling of her breasts and, particularly, Lahaia's breast-feeding are clear examples of breasts creating an experience of abjection (Kristeva I982), or in Cook Islands terminology, a "stink." Abjection occurs, according to Kristeva, when a classificatory boundary is transgressed, creating a sense of repulsion at the disruption of seemingly discrete boundaries, in this case between sexuality and motherhood.

The audience's experience of abjection towards the contestants' breasts was further heightened by the birth of Lahaia's dog-child. But rather than blur the boundaries between motherhood and sexuality, this "birth" points to a wider category crisis. As Garber has suggested, the transvestite figure is an indicator of a category crisis, "a failure of definitional distinction, a borderline that becomes permeable, that permits of border crossings from one (apparently distinct) category to another" (I992, I6). Lahaia's giving birth, as the performative rupture of the human-animal divide, similarly acts out a crisis elsewhere: the opposition between local and Western. As I indicated earlier, performances that combined local and Western forms of drag were not well received, in part because of differences and tensions between Western and Cook Islander understandings of sexual and gender identity. Laelae identity is bound to a collective, relational self and the performance of gendered roles. This configuration of sex and gender differs markedly from Western ideas of personhood where sexuality is thought to hold the key to an individual's gender identity.

With these differences between local and Western understandings of gender and sexuality in mind, it makes sense that those performers in the 1998 Drag Queen competition who attempted to combine categories of local and Western notions of drag failed. This failure can best be represented by the birth of Lahaia's bizarre and socially indigestible dogchild—a highly abject hybrid. In their assessment of the show as "stink," the Cook Islands audience quickly realized the two categories, local and Western, are incommensurable. Perhaps because of my intellectual investment in models that imagine cross-cultural encounters as creative processes, it has taken me far longer to work it out. 


\section{Conclusion}

In this article I have argued that aspects of the I998 Drag Queen competition represented a category crisis between local and Western understandings of gender-masculinity, femininity, and "third gender"-and sexual identities. I have suggested that this crisis demonstrates the way notions of sex and gender are bound to understandings of personhood, to the relationship of individual motivations to collective obligations. I have used Garber's analysis of the way in which a "category crisis" in one area can indicate dissonance in other aspects of social life. I have also adopted Kristeva's notion of abjection, as it allows us to grasp the way these crises are resolved and borders re-established. The result of abjection is a process of expulsion of a foreign element perceived as "not-me" (Butler I990, I33). Thus abjection is a form of boundary maintenance that serves to consolidate dominant forms of categorization and identity. The audience's reaction to Lahaia's dog-child can be seen as an enactment of this process, whereby threats to local identities, and attempts to maintain them, are increasingly prominent in the contemporary global era. ${ }^{6}$

This is not to suggest that all forms of exchange that take place between Cook Islands and Western ideas and practices produce a response of abjection. There are many instances in which local and non-local ideas and practices are productively combined, accommodated, adopted, and reworked. However, the 1998 Drag Queen competition draws attention to the way people think about cross-cultural encounters through metaphors that privilege engagement and creative co-production, and highlights the possibility that cross-cultural encounters are not necessarily productive and do not always result in happy hybrids.

\section{Notes}

I The Cook Islands are a group of fifteen islands in central Polynesia. Rarotonga, the administrative capital of the group, has a population of around Io,०००. Approximately 6,000 inhabitants reside in the "outer islands." The islands have been self-governing in "free-association" with New Zealand since 1965. The associated state relationship means that Cook Islanders have local political autonomy as well as automatic entry to, and dual citizenship with, New Zealand, where approximately 52,000 Cook Islanders reside. 
2 A number of Pacific Islander scholars and artists have explored the personal identity politics of "third gender" individuals; see, for instance, McMullin 200I, and Xian and Anbe 200I.

3 While Tsing's idiom of friction includes difference and minimal repulsion, her work emphasizes attraction. Later in this article I examine the process of repulsion that is produced through contact and contiguity, to suggest that crosscultural encounters are not a simple opposition of creative and positive versus non-generative and negative.

4 Lee Wallace has provided a fascinating, albeit different, understanding of homophobic disavowal with regard to same-sex practices in the Pacific (2003).

5 Nineteenth-century missionization in Polynesia had a clear influence on shaping indigenous notions of domesticity and motherhood. Cleanliness had moral implications for Christian missionaries, who saw domestic and personal hygiene as signs of conversion to "civilized" religious belief (see Jolly and Macintyre I989).

6 However, given the differential constructs of personhood, the distinction is less between "me" and "not-me" and more between "we" and "not-we."

\section{References}

\section{Alexeyeff, Kalissa}

2000 Dragging Drag: The Performance of Gender and Sexuality in the Cook Islands. In The Politics of Dance, edited by Rosita Henry, Fiona Magowan, and David A B Murray. Special Issue of The Australian Journal of Anthropology I 2 (3): 253-260.

2004 Sea Breeze: Globalization and Cook Islands Popular Music. In World Music: Politics, Production and Pedagogy, edited by Karl Neuenfeldt, Peter G Toner, and Stephen A Wild. Special Issue of The Asia Pacific Journal of Anthropology 5 (2): I45-I 58.

forthcoming If I could say it, I wouldn't have to dance it. In Transgressive Sex, Transforming Bodies, edited by Fiona McGowan and Hastings Donnan. Oxford: Berghahn Books.

Altman, Dennis

I996 On Global Queering. The Australian Humanities Review 2 (July-September). http://www.lib.latrobe.edu.au/AHR/archive/Issue-July-I996/ altman.html [accessed 23 July 2007]

200I Rupture or Continuity? The Internationalization of Gay Identities. In Postcolonial Queer: Theoretical Intersections, edited by John C Hawley, I9-4I. New York: State University of New York.

Appadurai, Arjun

200I Globalization. Durham, NC: Duke University Press. 
Besnier, Niko

I994 Polynesian Gender Liminality Through Time and Space. In Third Sex, Third Gender: Beyond Sexual Dimorphism in Culture and History, edited by Gilbert Herdt, 285-328. New York: Zone Books.

2002 Transgenderism, Locality, and the Miss Galaxy Beauty Pageant in Tonga. American Ethnologist 29:534-566.

Butler, Judith

I990 Gender Trouble: Feminism and the Subversion of Identity. New York: Routledge.

Cannell, Fennella

I995 The Power of Appearances: Beauty, Mimicry, and Transformation in Bicol. In Discrepant Histories: Translocal Essays on Filipino Cultures, edited by Vicente L Rafael, 223-258. Manila: Anvil Publishing.

Elliston, Deborah A

I999 Negotiating Transnational Sexual Economies: Female Mahu and SameSex Sexuality in "Tahiti and Her Islands." In Female Desires: Same-Sex Relations and Transgender Practices Across Cultures, edited by Evelyn Blackwood and Saskia E Wieringa, 232-252. New York: Columbia University Press.

Foucault, Michel

I978 The History of Sexuality. Volume I: An Introduction. New York: Vintage.

Garber, Marjorie

I992 Vested Interests: Cross-Dressing and Cultural Anxiety. London: Penguin Books.

Herdt, Gilbert

I994 Third Sex, Third Gender: Beyond Sexual Dimorphism in Culture and History. New York: Zone Books.

Howes, David, editor

I996 Cross-Cultural Consumption: Global Markets, Local Realities. London: Routledge.

Iwabuchi, Koichi

2002 Recentering Globalization: Popular Culture and Japanese Transnationalism. Durham, NC: Duke University Press.

Jackson, Peter

I996 The Persistence of Gender: From Ancient Indian Pandakas to Modern Thai Gay Quings. Meanjin 55 (I): I IO-I 20.

Jolly, Margaret

I997 From Point Venus to Bali Ha'i: Eroticism and Exoticism in Representations of the Pacific. In Sites of Desire, Economies of Pleasure: Sexuali- 
ties in Asia and the Pacific, edited by Lenore Manderson and Margaret Jolly, 99-I 22. Chicago: University of Chicago Press.

Jolly, Margaret, and Martha Macintyre, editors

I989 Family and Gender in the Pacific: Domestic Contradictions and the Colonial Impact. Cambridge, uk: Cambridge University Press.

Kristeva, Julia

I982 The Powers of Horror. New York: Columbia University Press.

Levy, Robert

I973 The Tahitians: Mind and Experience in the Society Islands. Chicago: University of Chicago Press.

Lo, Jacqueline

2000 Beyond Happy Hybridity: Performing Asian-Australian Identities. In Alter/Asians: Asian-Australian Identities in Art, Media and Popular Culture, edited by Ien Ang, Sharon Chalmers, Lisa Law, and Mandy Thomas, I 52-I68. Annandale, NSw: Pluto Press.

Mageo, Jeannette M

I996 Samoa, on the Wilde Side: Male Transvestism, Oscar Wilde, and Liminality in Making Gender. Ethos 24 (4): 588-627.

Martin, Fran

2003 Situating Sexualities: Queer Representation in Taiwanese Fiction, Film and Public Culture. Hong Kong: Hong Kong University Press.

McClintock, Anne

I995 Imperial Leather: Race, Gender and Sexuality in the Colonial Context. New York: Routledge.

McMullin, Dan Taulapapa, director

200I Sinalela. Beta SP video, 3 minutes. Sāmoa.

Shore, Bradd

I98 I Sexuality and Gender in Samoa: Conceptions and Missed Conceptions. In Sexual Meanings: The Cultural Construction of Gender and Sexuality, edited by Sherry B Ortner and Harriet Whitehead, I92-2 I 5. Cambridge, uk: Cambridge University Press.

Stoler, Ann L, and Frederick Cooper

I997 Between Metropole and Colony: Rethinking a Research Agenda. In Tensions of Empire: Colonial Cultures in a Bourgeois World, edited by Frederick Cooper and Ann L Stoler, I-58. Berkeley: University of California Press.

Stoller, Paul

I995 Embodying Colonial Memories: Spirit Possession, Power, and the Hauka in West Africa. New York: Routledge.

Tsing, Anna

2002 The Global Situation. In The Anthropology of Globalization: A Reader, 
edited by Jonathan X Inda and Renato Rosaldo, 453-485. Malden, MA: Blackwell Publishers.

2005 Friction: An Ethnography of Global Connection. Princeton, NJ: Princeton University Press.

Wallace, Lee

2003 Sexual Encounters: Pacific Texts, Modern Sexualities. Ithaca, NY: Cornell University Press.

Xian, Kathryn, and Brent Anbe, directors

$200 \mathrm{I}$ Ke Kulana He Mahu: Remembering a Sense of Place. vHs (Digital Video), color, 67 minutes. Written by Kathryn Xian; produced by Kathryn Xian, Jaymee Carvajal, Brent Anbe, and Connie M Florez; distributed by Zang Pictures, Inc, Honolulu.

Young, Iris Marion

I990 Throwing Like a Girl and Other Essays in Feminist Philosophy and Social Theory. Bloomington: Indiana University Press.

\section{Abstract}

Male to female cross-dressing and performing have a long indigenous history in the Cook Islands. In recent years, Western-style drag shows have also been included in the Cook Islands cross-dressing repertoire. This article takes the highly cosmopolitan vehicle of the drag show and uses it to track the relationship between local and global models of gender and sexuality. It examines ways in which the iconography of domesticity and motherhood has been used to signify an uneasy relationship between local and global ideas of sexuality and gender.

KEYWORDS: globalization, gender, sexuality, performance, Cook Islands 